\title{
国際化時代に打ける医学教育と研究
}

\author{
相原 薫* \\ 日本医科大学中央龟子影锺鏡研究施設
}

\begin{abstract}
Medical education and research in the era of internationalization
\end{abstract}
\section{Kaoru Aihara}

Central Institute for Electron Microscopic Researches Nippon Medical School

はじめに

現代はいろいろな多角的な意味で国際化 (Internationalization)の時代といわれている.こ れは交通手段, Telecommunication の発達により 各国間の障壁がとりはずされつつあり，国境をあ まり意識することなく活動を行いらるといら現実 があるからであり，医学の面でもその例にもれな (1). 本学中央電子顕制鏡研究施設は世界でも例 をあまりみないWHO 指定研究研修センターと して活動してきたが2 ゙7),その経験から現代の医学 教育, 研究には一定の法則性（表 1) があり,こ れらの流れを理解しておくことは今後の展開をら らなら上で, 必ずしも無駄ではないと考劣るので, ここに紹介する次第である。

\section{1. 現在の医学を理解する上での基本概念}

この医学に対する新しいフプローチの基本は, 1978 年旧ソ連邦カザフ共和国アルマタ市 (Almata）で行われた第 30 回 WHO 総会に括ける西 暦 2000 年までにすべての人々に健康を(Health for all by the A.C. 2000) のスローガンにもとず

\footnotetext{
*施設長, 教授

世界保健機関 (World Health Organization, WHO) より電子昰微鏡診断学についての研究研修協力セン ターとしての指定をうけている(WHO Collaborating Centre for Research \& Training in Diagnostic Electron Microscopy). (1984 年 1996 年).
}

いているといってよい.(表 2 )。西暦 2000 年まで にあと 7 年をのこすばかりとなった現在では，こ れを 2010 年にのばすといら動きるみられるが, 少 なくとも現在では，まだこのスローガンは生きて いるといってよい, 癌, HIV/AIDS, 環境污染, 災害にもとつく障害等解決をせまられている命題 も少なくないが, 天然痘が地球上から消隇したり， 急性前角灰白質炎（poliomyelitis anterior）か， 近い将来西太平洋地域から絶減しらるとい5明る い予湘がたてられるにいたっている5゙.従って, 医 学教育, 研究の実施到達目標が, このスローガン の達成に寄与するといら立場から行われるのが望 ましいといらことは論をまたない。このような観 点から現代の医学教育と研究の動向についていさ さかの見解をのべてみたい。

(1) 医学教育の動向

現代の世界の医学教育の源流は米国の Illinois 大学の Center for Medical Education (CME) により提唱された教育原理にもとついているとさ れる、WHOはいちはやくこの原理(図 1 ) に着目 し, 各地域に Regional Teachter Training Centre (RTTC) の創設をはかり，その普及をはかっ た. WHO の地域事務局は世界で 6 局にわかれて おり, 我国が所属する西太平洋事務局 (Regional Office for the Western Pacific, WPRO, WHO) は, すでにオーストラリフ, シドニーにある University of New South Walesに同様センターを 設けており，現代は teachterのみならず，すべて 
表 1 National Teachter Training Centre の活動計画の例

(Seoul National Uni. College of Medicine. NTTC)

\begin{tabular}{|c|c|c|}
\hline $\begin{array}{l}\text { A Educational Service for the } \\
\text { Health Professional Faculty }\end{array}$ & $\begin{array}{l}\text { B Junior Faculty Development Pro- } \\
\text { gram }\end{array}$ & $\begin{array}{l}\mathrm{C} \text { 実地医家のための生涯数育 } \\
\text { (Continuing Medical Education) }\end{array}$ \\
\hline 1 Faculty Development Program & \multirow{16}{*}{$\begin{array}{l}\text { ソゥル大学医学部と協カしてMS/ } \\
\mathrm{PhD} \text { プロクラムを提供する. } \\
\text { その祭, 派㟟される大学の Faculty } \\
\text { Appointmentをるつことが条件とな } \\
\text { る. }\end{array}$} & (1) Day-Release Course 全日コース \\
\hline 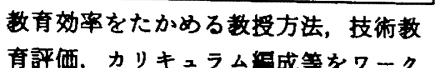 & & (2) Evening Course \\
\hline ショッブ, セミナー会㘘等より得す & & $\begin{array}{l}\text { タ方 } 2 \text { - } 3 \text { 時間 } 1 \text { 週から } 3 \text { 週にかけて } \\
\text { おこな } 5 .\end{array}$ \\
\hline 2 政府および他の教育機网への榙問 & & (3) Intensive Week Course \\
\hline センターは政府および他の健康教育機 & & 1 週間の全日コース \\
\hline $\begin{array}{l}\text { 闺に対して, 教育政策，実施計画につ } \\
\text { いて助言を行 } 5 .\end{array}$ & & $\begin{array}{l}\text { Bedside, Rounds Panel discussion } \\
\text { Ground rounds Tutorial を集中的に }\end{array}$ \\
\hline 3 研究と開発 & & 行5. \\
\hline $\begin{array}{l}\text { センターは韓国教育事情に亮合した教 } \\
\text { 育計画とカリキュラム成登を行ら }\end{array}$ & & $\begin{array}{l}\text { (4) Self-Instructional Monograph の } \\
\text { 提供 }\end{array}$ \\
\hline また国家試非は尃門医試検のよらな教 & & 自習用教本を配布する。 \\
\hline 育活動の各分野での評価方法の標準 & & (5) Self-Assessment Program \\
\hline 化，通正化にも従事する。 & & 自習および自己学習評価ブログラムを \\
\hline 4 料蒐集之配布 & & 提供する。 \\
\hline センターは㷹国健康教育制度，人的資 & & (6) 訪問サーピス \\
\hline $\begin{array}{l}\text { 源等に関する情報を蒐集し，その要約 } \\
\text { を目布する. }\end{array}$ & & $\begin{array}{l}\text { センターは生涯教育の計画実施のため } \\
\text { の現地におすむいて指尊する. }\end{array}$ \\
\hline 5 Medical サービス & & \\
\hline $\begin{array}{l}\text { Audio-visual Display に网するメデ } \\
\text { フを作成し配布する. }\end{array}$ & & \\
\hline
\end{tabular}

表 2 最近の医学教育改善の動き》

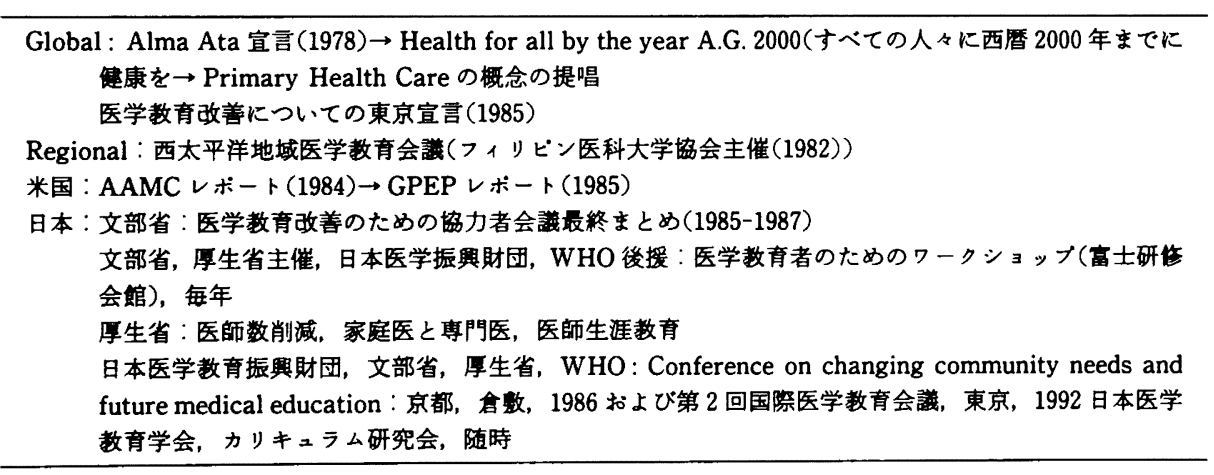

の保健健康要員の適正な養成にもかかわりあらと いうことで，近年同センターはRegional Training Centre for Health Development (RTCHD) と改称されだ. その協力のすとで各国に National Teachter Training Centre (NTTC)
を設立し，適正な教育実際の展開にあたるとして いる. 当該地域においてはNTTCは韓国, フィリ ピン, マレーシア等に設置され，中国においては 本学と学術交流協定を締結している中国医科大学 に設置された医学教員養成センターがほぼ同様な 


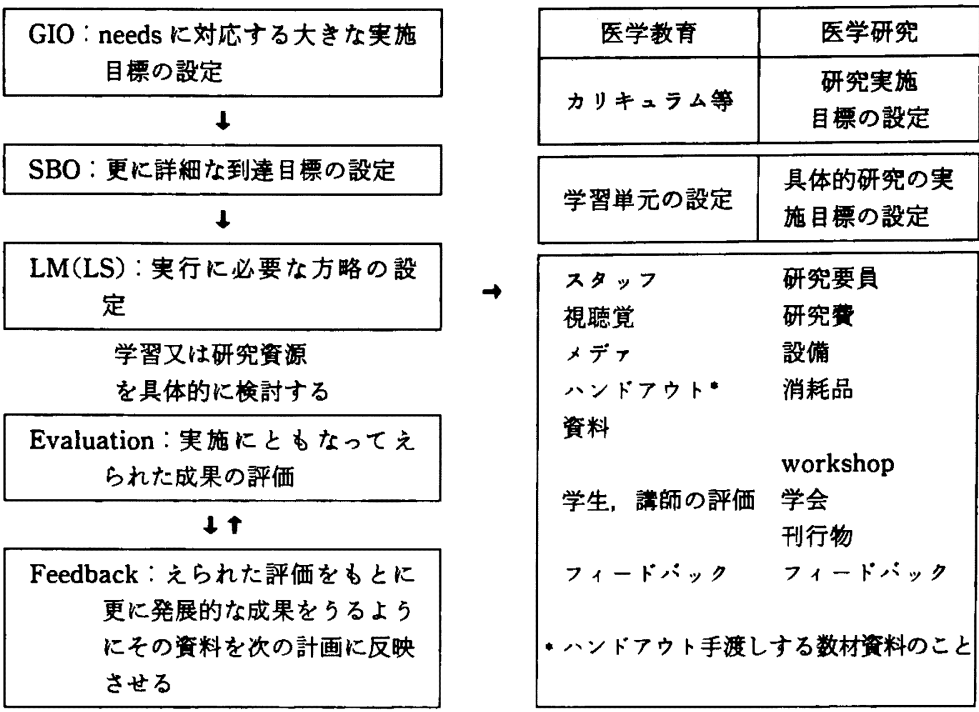

図 1 医学教育ならびに研究の両分野に適用できる計画の実施様式

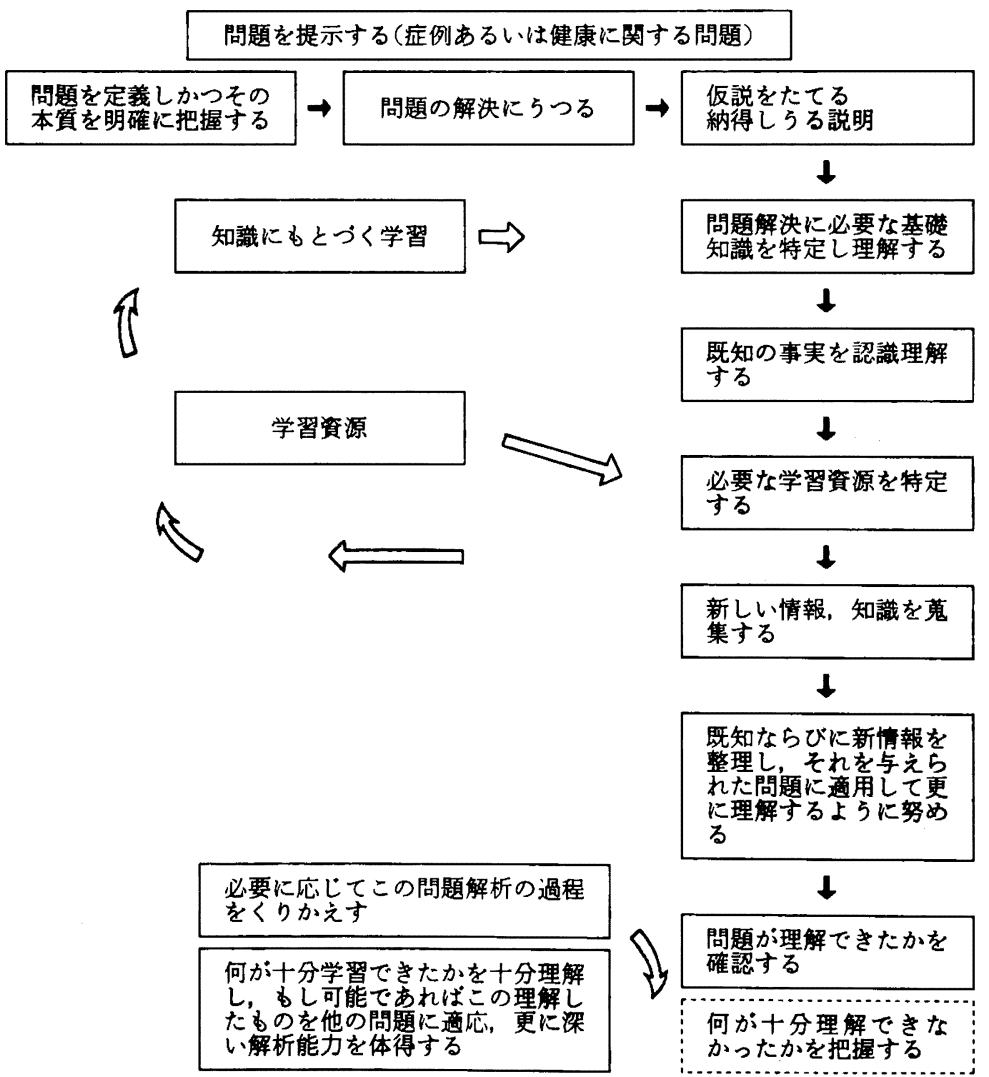

図 2 問題解決型学習のステッブ (MacMaster 大学の例) 


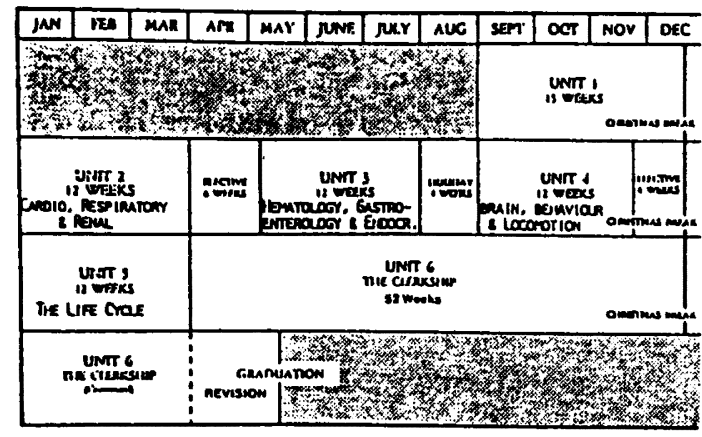

1. 3 年間で実施する，2，学生の経歴はさまざまであ る. 3. 自己学習指向型のプログラムである. 4. 問題 にもとつきき，また問題解決型の学習である. 5. 学際的 なフプローチである.6. 小タルーブ指導型カリキュラ ムである.7. カリキュラム実施間同時学生評価一最終 試験は行わない.

Problem-based learning と problem-centred learning

注）この McMaster 大学のカリキュラムの特徽は, problem-based learning である。健康管理に関する問 題を, 知識の活用とこの概念の理解のために提示する. カリキュラムが進行すると, problem-solving の技能 の養成を行いらる. Problem-based learning において は事前に情報を与えない. Problem-based learning は problem-centred learning とはことなっている. Problem-centred learningに扔いては事前にえた正 式な講義による知識をるちいて問題の解決を試みる。 Problem-based learning はより適切であるが実行が やや困難である. Problem-centred learning はやや活 性をかくが実施が比較的容易である。この両者の方法 は併用して能率的な学習を行うことができる。

図3カリキュラム計画表 (McMaster大学, L.A. Branda)

機能をむつとされている9 . RTCHDは 1974 年よ り毎年組織開発 (Organizational Development), カリキュラム開発 (Curriculum Development) 等 の医学教育, 研究上の重要課題についての研修課 程 (Training Course) を開催するととすに MS, さらには Ph.D. プログラムを提供するにいたっ ている8).これらの Training Course には, 例年我 国からす数名の出席者があり，研修修了後それぞ れの分野で活矅するにいたっている，各国におい $\tau$ National Teachter Training Centre (NTTC) が設置され，人材養成に中核的な役割りをはたし ていることはすでにのべたが(韓国, Seoul 国立大 学, フィリピン National Philippine University
System, マレーシア University of Malaysia), 同様な教育活動は Mac Master 大学（カナダ, 図 2, 3), Jefferson 医科大学, Harvard 大学 (New Pathway Course), Ben Gangurion 大学 (イスラ エル), Limburg 大学 (オランダ), 等において精 力的に教育の改善がされている. 伝統的なアカデ ミックな医学部と新しく創設された医学部のカリ キュラムをめぐる対立も両者間の相互理解とあゆ みよりにより解決の方向にむかいつつあるすのと いえよら ${ }^{11-13)}$ (表 2). 我国においてもこのよらな 新しい教育理念の普及と徹底をはかるために，日 本医学教育学会を中心に NTTC の設置が計画さ れたとされているが，いまな拉完のはこびには なっていない, しかし, 本学会, 文部省, 厚生省 主催（従来はWHO も後援に加わっていた）の例 年 12 月上旬に静岡県裾野市で行われる医学教育 者のためのワークショップ（帝人研修センター） がその役割りをはたしているものと考えられる (表 2 ).

（2）これらの教育活動により普及がはかられる 原理と実際

この教育原理は従来の伝統的医学教育をらけて きたすのには，理解しずらい面もあるが，筆者が Seoul 国立大学医学部の NTTCにおいて講演し たときの経験がそれを直接的に反映しているもの といえよう、講演を終了したところ司会者がフン ケート表を出席者に渡し, 講演の内容, 表現力, 理解, 説得させる能力等についての講師について の評価をもとめた.「3 尺さがって師の影をふま ず」といら古い感覚をもった筆者にはその行動が 奇異にらつり, その当時は理解できなかったが, その後富士のワークショップに出席したり，その 他の教育活動に従事してみると、これが新しい教 育理念にもとつく第三者評価の一端であることが 理解でさるようになった。. 現在, 強調されている 自己評価む，第三者評価の一歩前段階であること が示されたわけである。また，大学設置基準の大 幅な改革, 医学教育の改善への大きな流れは, こ のような潮流にもとついているといえよう。 
表 3-1 西暦 2000 年までにすべての人々に健康をとの標語に対応して健康システムに対する基本概念の变遷を示す チャート

\begin{tabular}{|c|c|c|c|}
\hline & 基礎医原実施期 & 基碐医寮サービス充実期 & ブライマリー・ヘルスケフー展開期 \\
\hline (1)概 & $\begin{array}{l}\text { 医療施設を通した健 } \\
\text { 政策 }\end{array}$ & $\begin{array}{l}\text { 医瘦施設を通した健康政策の拆大充 } \\
\text { 期 }\end{array}$ & \begin{tabular}{|l} 
西暦 2000 年までにすべての人々に律康をとの標 \\
語によってカバーするすべての分野 \\
\end{tabular} \\
\hline (2)目 & 疾病の治棠 & 予防医学に重点をおく & 同様である \\
\hline (3)ブログラムの内容 & 大半は医㬌行為 & 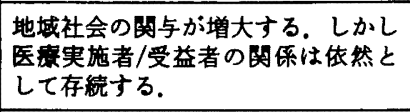 & 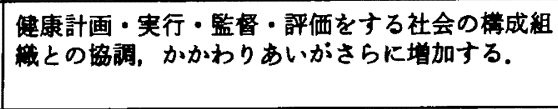 \\
\hline (4)実施方法 & $\begin{array}{l}\text { 医療施行者/受益者 } \\
\text { との相互関係によ } \\
\text { る. }\end{array}$ & $\begin{array}{l}\text { Health sector とのかかわりあいに } \\
\text { おいて高度なサービスの增加 }\end{array}$ & $\begin{array}{l}\text { 健康計画の発展のための intersectoral approach } \\
\text { の実現 }\end{array}$ \\
\hline 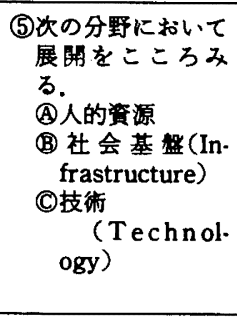 & 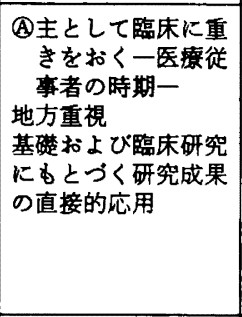 & 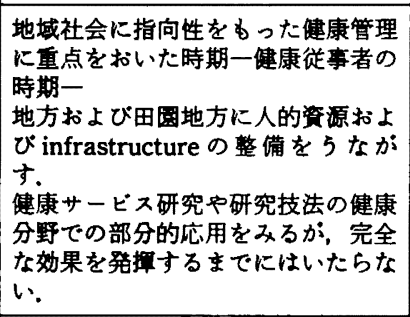 &  \\
\hline (6)資源のあり方 & 地域社会指向性 & $\begin{array}{l}\text { 疾患の减少，死亡率の低下を目標に } \\
\text { する. }\end{array}$ & 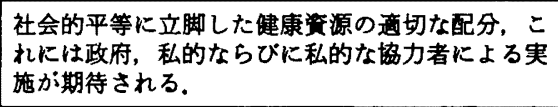 \\
\hline (7)評 & 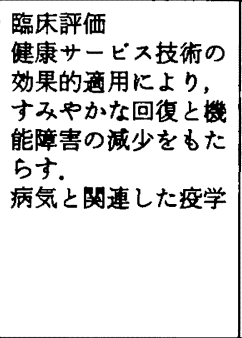 & 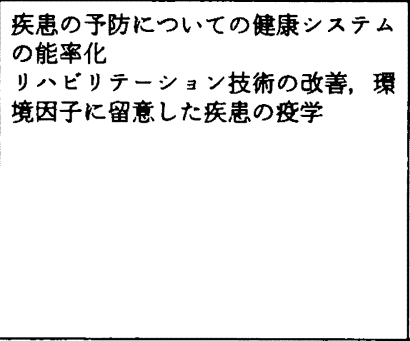 & 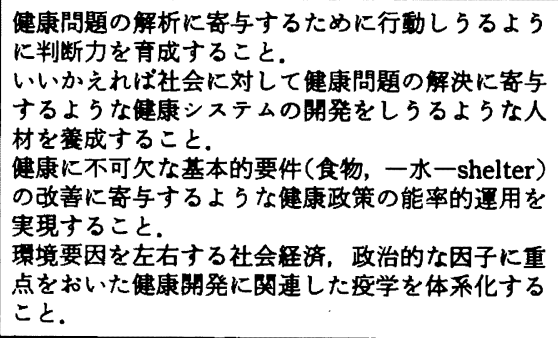 \\
\hline
\end{tabular}

表 3-2 WHO Regional Training Centre for Health Development の活動内容（1991）

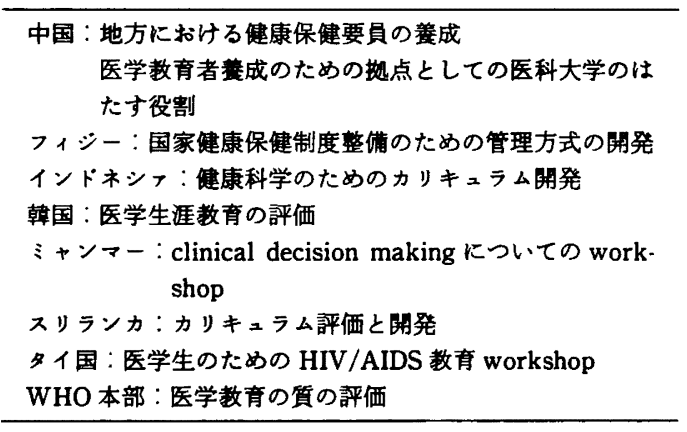

\section{2. 新しい教育原理}

すべての教育課題に一般目標 (General Instructive Objectives, GIO), 特別行動目標 (Special
Behavioral Objectives, SBO) を設定し、これら の目標を達成するために学習対策, または方法 (Learning Strategy, LSまたはLearning Method，LM）を策定し，その実施結果を評価 (Evaluation, EV), その行為をくりかえすことに より,さらに活動にいかすこと(Feed back, FB) により，所期の教育目標を達成しょうというもの である、評価のあり方が問題となることがしばし ばであり，その代表的なものが試験(test)である. これには，(1)記憶レベル，(2)想起レベル，(3)問題 解決レベル等があり，できうれば学習者の適切な 評価のためには, 問題解決レベルでの設問が望ま しいとされているにいたった。 また，問題解決の ために遭遇する抵抗因子をたんねんに除外する方 式の分析 (Force-Field Analysis, FFA) の必要 
性, その結果にもとつく変改目標の設定や, 教育, 研究管理上，第三者の助言をむとめる，いわゆる Change Agent の必要性を強調しようとするもの である.このような背景から本邦においての医学 教育に自主学習中問題解決型 (problem-oriented または problem-solving type）の学習方式が急速 にとりいれられつつあるのは周知のごとくであ る.一般に医学の発展は次の三階段にわけられる とされる（表 3 ）. すなわち，1）基礎的医学発展 期，2）医学の応用開発期，3）Primary Health Care System の発展期に大別され，現在は2)から 3)への移行期にあると考えられ，医学教育, 研究 はこの時相の上で理解されるべきであろう。いい かえれば医学教育, 研究もこの社会基盤の構筑改 変の動線の上にあるといえよ5。自主学習, 問題 解決型学習, ベッドサイドティーチング, チーム 医療，生涯教育等の考方方はすべてこの原理にも とついて理解されよら。
（1）生物，医学研究ひいては健康科学研究 (Biomedical Research, Health Systems Research HSR) の動向

現在の生物, 医学研究の発展には瞠目すべきも のがある.Abdelommé 博士（前 WHO 本部事務 局次長）によれば研究展開上の戦略には，次の内 容がふくまれるという。それには，(1)かにして 疾患が生じるか? (2)その病因の解明にもとつ’ き，いかにしてその疾患が予防できるか？ また， 発症した場合いかにして疾患をコントロールしら るか? (3)研究を展開する上でいかなる組織開発 が必要であるか等についての配虑が必要であると い5.

（2）世界的にみた医療，医学研究展開について の組織

現代はすべての面で国際化がすすみつつあり， 医学研究もその例にもれない，そこで WHOは本 部機構のなかに世界レペルにおける健康研究諮問 委員会 (Global Committee on Health Research,

表4-1 西太平洋地域諸国の研究機構の実態

\begin{tabular}{|c|c|c|c|c|c|c|}
\hline オーストラリフ & 国 & フイジー & 本 & マレーシフ & =ュージランド & フィリビン \\
\hline 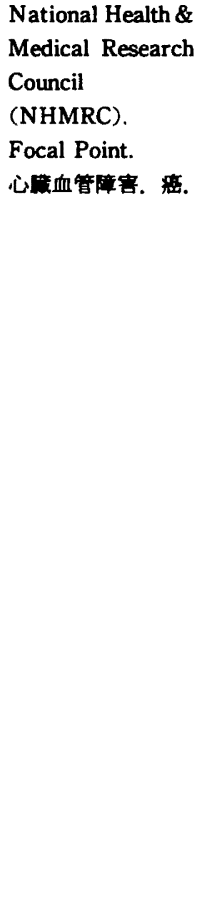 & 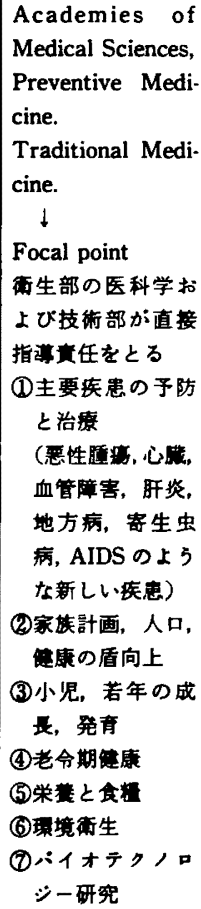 & $\begin{array}{l}\text { National Health } \\
\text { Research } \\
\text { Council.(1982) } \\
\quad \downarrow \\
\text { Focal point. }\end{array}$ & $\begin{array}{l}\text { National Health } \\
\text { Research Council } \\
\text { はない. }\end{array}$ & $\begin{array}{l}\text { IRPAC } \\
\text { Intensification of } \\
\text { Research in prior- } \\
\text { ity area 原理にす } \\
\text { とついて科学技術 } \\
\text { 省が予算をわりあ } \\
\text { てろ. } \\
\text { Kuala Lumpurの } \\
\text { 医学研究所(1980) } \\
\text { が实流してい } \\
\text { る }\end{array}$ & $\begin{array}{l}\text { Medical Research } \\
\text { Council か: Focal } \\
\text { point として 機 } \\
\text { している } \\
\text { それは } \\
\text { (a) Biomedical } \\
\text { Research Commi } \\
\text { ttee } \\
\text { (b) Public Health } \\
\text { research Commit- } \\
\text { tee としてさらに } \\
\text { 機能をしている }\end{array}$ & 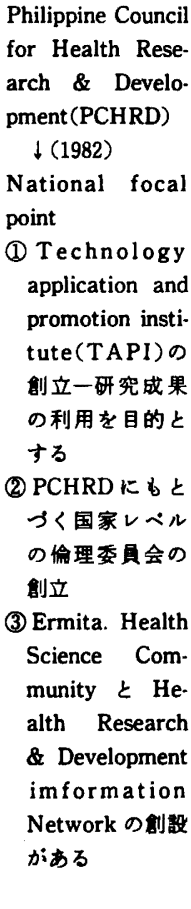 \\
\hline
\end{tabular}


表 4-2 西太平洋地域諸国の研究機構の実態

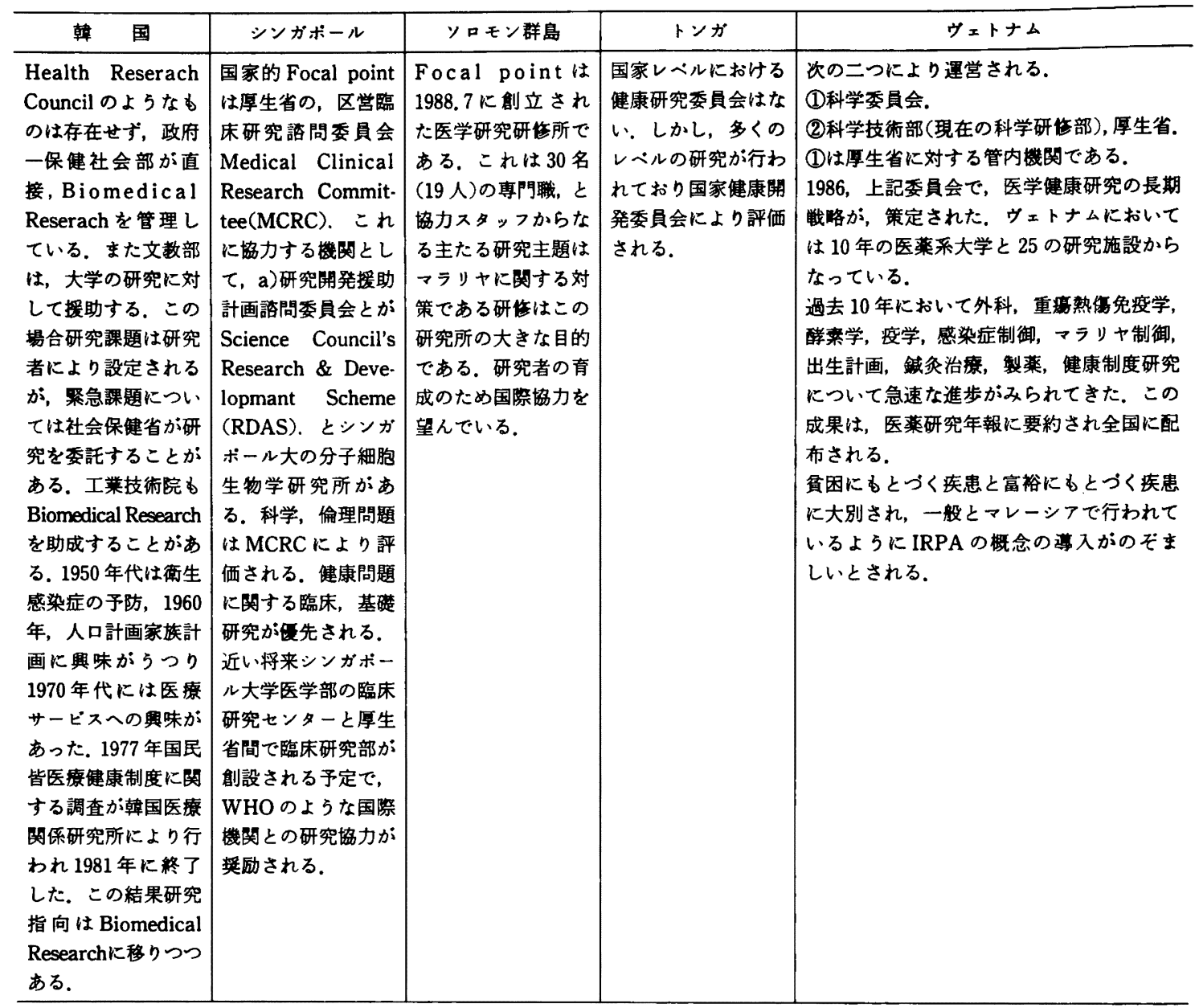

GCHR）を設置し，西太平洋地域事務局レベルに おいても同様な, 健康研究諮問委員会 (Western Pacific Regional Committee on Health Research, WPRCHR)を設立し, 定期的に開催し ている，それらの健康研究に関する政策を各国に すみやかに普及させるために国家レベルにおける 研究委員会 (National Health Research Council, NHRC)，またはその機能に対応する組織(Analogous body）の設立をすすめている（表 4 ）.これ は健康科学がきわめて多岐にわたり，また経費も 多額にのぼることから cost-effectivenessを考え て，上り効率のよい研究を行い，その成果を速や かに波及させようとするすので，本邦には公式に はこのような委員会が存在しない.しかし，厚生
省が主催する厚生科学会議や脳死や臟器移植等に 関連して各学会の連携による steering committee の設置等, analogous body の性格をむつ組織 への胎動がみられるのは注目する必要があろう。 このように健康科学に関する National Research Council 類似組織をもってする展開が今後予測さ れ, GCHR, WPRCHR が行 ら研究政策決定の動 向を無視することはできない，さらに上記委員会 は，新らたに医学研究に対応する疾患分類を提唱 している5!。それは次のような考え方である。

\section{3. 新しい疾患分類の概念の提唱}

1) 受精時発症する疾患 (pre-natal diseases determined at fertilization) 
単一の遗伝子の欠損と chromosomal aberrationにより生じるとされる。

2）受精後生じるか出生前に発症する疾患 (prenatal diseases determined after fertilization)

これらの疾患は必ずしす受精時に成立するもの ではなく，胎児の子宮内成育期に打いて発症する とされる.

これにはさらに次の 2 群が存在することが考え られている.i） 1 群：胎生初期に発症し着床期, または胎生期初期における胎内環境の変化により 生じるとされる。ii） 2 群：明らかに特定しうる 原因，たとえば風疹，thalidomide，重金属中毒, 妊娠中におけるョード久乏症, 放射線障害, タハ 二喫煙，薬剂投与や低体重状態によるもの.

3）物質欠乏症, 栄養不良等にもとづき生後に発 症する疾患群 (Post-natal diseases due to deficiencies and hazards. Diseases of Poverty)

これは食糧不足, あるいは栄養不良の直接, ま たは間接の影響により生ずるもので賓困にもとづ く疾患群ともいわれる。発展途上国に打いて社会 的基盤が確立していないところでは，いまなお問 題としてのこされているところが少なくない，フ ルコール，麻薬等の乱用も発症を加速させる。

4）適応不適にもとづき出産後に発症する疾患 (Post-natal diseases due to Maladaptation. Diseases of affluence, 富裕にもとつ き発症する疾患)

先進国および急速な近代化，工業化をみる諸国 における疾患の様相はいちじるしい変貌をとげて きた。たとえば心臓血管系障害, 代謝系障害, 環 境污染にともなら疾患, 老年病, 精神神経障害, 悪性腫湯等である。多くの場合, 大気污染, 産業 廃棄物としての化学薬品, 農薬, 食品添加物, 交 通量の増加, 放射性物質による污染, 生物医学研 究, 治療の実施による生体への障害, ハシランスの わるい食事等多䀞にわたる原因にもとづき発症す ることが多く，これらは適切な指針を指示実行す ることにおいて改善されらる。このように疾患を 画一的に分類することには疑問の余地はあるが,
少なくとも病因論から疾患を理解し，将来の研究 発展に資する点では一考の価値があるすのと考光 られる。

\section{4. 生物, 医学研究が疾患の予防, 治療にはたし うる役割り}

以上述べてきたところで明らかなように, WHO の提唱している将来の needs に対応する本 質的な Primary Health Care Policy と, 我国で いわれている Primary Health Care とは理念の 上で大きなへだたりがみられることは否定できな い. 後者す日常医療に怙いて不可欠の概念である ことはいうまでもないが，前者の広義の理念に包 括され，その一部をなするのと考えられる。した がって Primary Health Care Policy は既述のよ うな医学教育と研究の抜本的改善とその展開も考 虑にいれたものであり，従来考えられていたよう な先端的学術研究, 伝統的な研究指向型の医学教 育, 研究と医療の現実的発展とは無縁であるとい ら理解はむはや成立しえない14（表 3）。これは本 邦を代表する医学部に国際保健学の大学院が新設 されたことにも，その動向の一端をらかがいしる ことができる、このよらな理解から近年長足の進 歩をとげてきた生物, 医学的研究の方法論, 蓄積 された成果はすみやかに体系化され，新しい医療 体系にくみいれられていくものと考えられる。た とえば遺伝子工学の診断, 治療への応用はめざ しく, 次世紀には 500,000 1,000,000にものばる 遺伝子が確認され Genom map が完成の域に達 すると考えられる. Virus 誘導癌の研究により多 くの oncogene の意義が明らかにされつつある. Oncogene の表現型, 生長, 促進, または抑制因子 の作用機序の解明により, 正常および病的細胞の cell cycle の本態解明が期待されよう.糖鎖工学の 発展も発癌機序の解明, ホルモン受容体の本態解 明に少なからず役割りをはたすものと考えられ る.また, 神経生物学, 神経化学の進歩もいちじ るしい，神経刺激伝導機序等神経，筋接合部の形 態と機能, 収縮蛋白の分子構造の解明, neuropeptide の発見, 行動精神神経学の発展の上に有意 義な知見をもたらした。 また, 細胞生物学の発展 
すみのがしえない、ホルモンの作用機序の解明と 受容体の構造の解明はホルモン疾患の診断と治療 上いちじるしい展開を示すにいたった，HIV/ AIDS ウイルスの研究す瞠目すべき進歩を示して いるが，本態の解明にはほどとおく，各方面から の研究展開がまたれている，また，生物活性物質 （生物トキシンをふくむ）の細胞・組織とのかかわ りあいが明確になりつつあり，炎症論の展開の上 でいちじるしい進歩をもたらした。また，臨床医 学の急速な進歩すみのがせない，大型災害に対す る対策も整備されつつある. 臨床医学の進歩は診 断, 治療, 予防のいずれの面にもみとめられる15). とくに診断的立場からみれば数学, 物理学, 推計 学のような純粋科学の進歩にささえられている面 が多い16). DNA組かえ法 (recombinant DNA 法), Monoclonal 抗体法等による感染症の診断, 治療法の開発, 覀性腫瘍の免疫療法, 精神病の酵 素補充療法, 先天性代謝疾患の分子遺伝学的手法 による治療, 呼吸器疾患の治療等について子瞠目 すべき所見がえられ，これらが急速に医療体系に くみこまれつつある17.
5. Health systems research の展開と Biomedical research とのかかわりあい

Bio-medical research の進歩はたゆまなくいき つくところをしらない.それにとすなって情報の 混乱, 適正でない情報の拡散, 医療体系へのあや まった組込み等について留意する必要がある，集 積される成果の効果的な活用にはそれなりのシス テムが必要となる。

そこで適正な technology の認識 (Delineation of appropriate technology）が必要となる。それ らの医療資源の体系化と有効利用を促進し，医療 健康科学体系に尊入する Health systems researchの概念が重視されるにいたった ${ }^{18)}$. ま た, 健康研究の方法論の訓練の必要性が重視され, これについての workshopが活発に行われるよ らになった.この研究活動を通して健康增進と効 果的な医療活動を実現する方策を策定しょうとい 5すのである(図 4).とくに新たに開発された科 学的方法論と,その展開によりえられた成果と解 決を迫まられている諸問題への対応に用いよらと

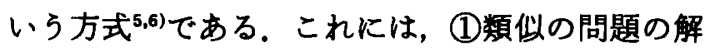

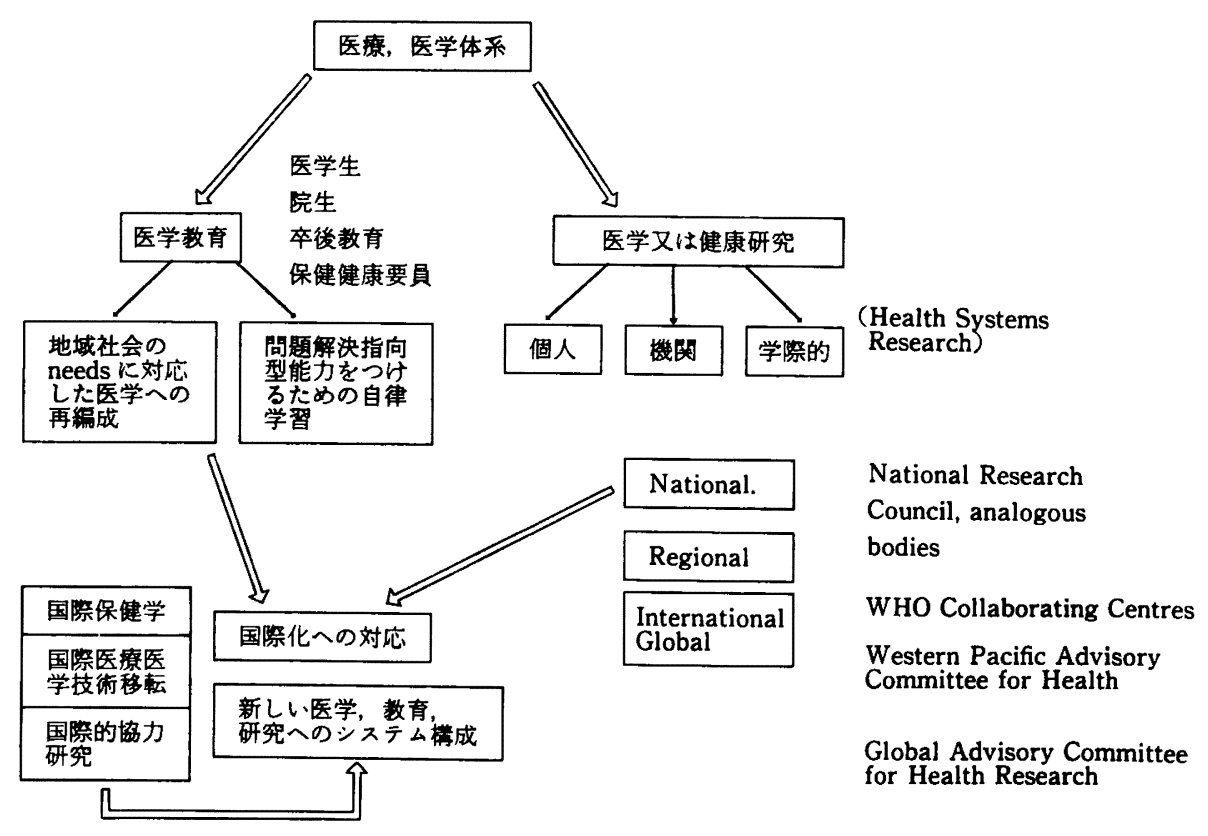

図 4 医療医学の将来予期される動向に関する flowchart 
決に，その技法を用いて同様な結果をうることが できるかどらかの再現性 (reproducibity) の評価 も必要である. (2)一つの主要問題を研究し, その モジュールを他の問題の解決に応用しらる能力の 養成，(3)原因を理解し，これを分析することによ り刺激之行動を概念化し健康問題の解決に役立せ らる能力 (behavioral research) の養成等の条件 を具備する必要がある ${ }^{18)}$. 研究遂行 (implementation）には経費の問題を配慮する必要がある ${ }^{19}$.

\section{6. 研究経費について}

研究の遂行には予算の計上とその円滑な支出の 執行が必要とされる。しかし，十分な予算が計上 される例はむしろ少ないといってょい.したがっ て予算の効果的，さらには能率的な支出がのぞま れる. 研究費の予算化には, i) 研究計画を立案し, それに予算を計上する一般的なやり方 (projectbased budgetting) と, ii）研究計画を遂行しなが ら予算を, きめこまかく支出する zero-based budgetting があるが, 昨今のように限られた予算で研 究をすることが多い場合はii)の方式をとり, 細心 の留意をはらい研究を遂行することが望ましいと される.このような管理能力の養成は従来比較的, 閑等視されてきたきらいがあるが，今後研究の cost-effectiveness を考える上で重要であると考 えられる ${ }^{20)}$. 従来の vertical research in depth は それなりの有用性があるが，今後は幅の広い基盤 をるつ horizontal Researchのモデルが重視され 将来は Social needs に対応する flexible な spiral typeのモジュールの作成が研究遂行上必要であ ると考えられる(Paik ${ }^{31)}$ )。

\section{7. 国際化時代における医学教育と研究のかか} わクあい

国際学術交流の流れほど我国においてつよく要 請されている命題は少ない. 文部省においても21 世紀において 10 万人の留学生をらけいれる構想 を進めており，多くの分野において，この目標達 成に努力しているのが現状である. Ventura はそ の surveyにおいて, 西太平洋地域における WHO fellowの $22.37 \%$ 旦本, 米国 $14.92 \%$, 豪州
14.23\%, 英国 16.44\%がしめているとい5.しか しながら，この推進には幾多の解決すべき問題が よこたわっているのも，また事実である。しかし， 開発援助の理論的研究のみならず，人材育成を念 頭においたカリキュラムをくみ, 現場中心に活躍 し、リーダーシップをとりらる人材育成の必要性 が認識されつつあり, 東京大学(国際保健学), 名 古屋大学 (国際開発研究科), 神戸大学 (国際計画 研究科), 埼玉大学 (国際開発専攻科) のような大 学院レベルでのコースが開設されつつあるのは注 目に値しょう。一般に我国においては物の国際化 がすすんでいるが，心の国際化は遅れているとさ れる. 国際学術交流のあり方に当事者同志の交流 によるもの (bilateral), あるいは多者間 (multilateral）の両方式であり，我国の国際化の流れに は能率および経済効果を重視するあまり，直接的 な交流をもってよしとするいわゆる負の国際化意 識が底流にあるといら批判には十分耳をかたむけ る必要があろ $5^{3,4)}$. それが我国の医学教育研究が 必らずしす近隣諸国から十分理解されない要因の 一つとしてあげられている。学位の制度にせよ M. S. まで授与している諸国がほとんどで, Ph.D. programmeの充実に我国が手をかしてこそ，本 当の国際交流の実が結ばれよう2).いずれにせよ 多少はんざつになることはさけられないにせよ, multi-lateral collaboration の道をえらぶことが, 現在の我国にもっともふさわしい方式のように思 われる.それには, 明確な実行計画 (plan of work), 研究遂行能力(implementation), さらに はこれを的確に評価し, 将来の発展にそなえると いら既述のモジュールをふまえることが不可欠で あろら。

\section{WHO 指定研究研修協カセンターnetwork}

すでにのべたように医学教育, 研究に国際的な 視野をむつことは不可欠であり，それぞれの国際 学会がその責任をはたしていると考えられるが, 近年注目されつつあるのは, WHO 指定研究研修 協力センターの network である. WHOは一定の 資質をそなえた研究施設を研究研修協力七ンター とし、て指定し GCHR, WPRCHR, national 
表 5 WHO 指定研究協カセンター一臨

1992年 2 月現在

\begin{tabular}{|c|c|c|c|c|c|c|c|}
\hline No & センター名 & センター長 & 指定分野 & 住所 - TEL - FAX & 指定日 & 指定日 & $\begin{array}{l}\text { 指定 } \\
\text { 期限 }\end{array}$ \\
\hline 1 & $\begin{array}{l}\text { 国立予防衛生研究所 } \\
\text { ウイス・リケッチ } \\
\text { ア部 }\end{array}$ & 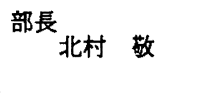 & フルボウイルス & $\begin{array}{c}\text { 于141 品川区上大崎 2-10-35 } \\
\text { Tel : } 3444-2181, \\
\text { Fax : } 3446-6286\end{array}$ & 1961 & \begin{tabular}{|c|}
1985 \\
19 Jun
\end{tabular} & 1989 \\
\hline 2 & $\begin{array}{l}\text { 国立予防街生研究所 } \\
\text { 渴内ウイルス部 }\end{array}$ & 第三室長 峰生 & ウイルス & $"$ & 1962 & $\begin{array}{c}1985 \\
23 \mathrm{Jul}\end{array}$ & 1989 \\
\hline 3 & $\begin{array}{l}\text { 国立予防菏生研究所 } \\
\text { ウイルス・リケッチ } \\
\text { ア部 }\end{array}$ & 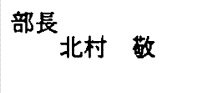 & その他のウイルス & " & $\begin{array}{l}1962 \\
\text { Jan }\end{array}$ & $\begin{array}{l}1980 \\
\text { May }\end{array}$ & 1983 \\
\hline 4 & $\begin{array}{l}\text { 北海道大学医学部 } \\
\text { 精神学教室 }\end{array}$ & 教授山下 & $\begin{array}{l}\text { 生物学的精神医学 } \\
\text { 及び精神衛生に䋨 } \\
\text { する研究・訓練 }\end{array}$ & $\begin{array}{l}\text { 干060 札幌市北区北15条西 } 7 \text { 丁目 } \\
\text { Tel : 011-716-2111, } \\
\text { Fax : 736-0956 }\end{array}$ & 1967 & $\begin{array}{c}1989 \\
31 \text { Jan }\end{array}$ & 1994 \\
\hline$\frac{\text { 終 }}{3}$ & $\begin{array}{l}\text { 国立予防衛生研究所 } \\
\text { ウイルス・リケッチ } \\
\text { ア部 }\end{array}$ &  & ボックスウイルス & & 1969 & 24 Nov & 1983 \\
\hline 5 & 国立予防衛生研究所 & $\begin{array}{l}\text { 副所長 } \\
\text { 徳永 }\end{array}$ & 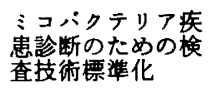 & $\begin{array}{l}\text { T141 品川区上大崎 } 2-10-35 \\
\text { Tel : } 3444-2181, \\
\text { Fax : } 3446-6286\end{array}$ & 1969 & $\begin{array}{l}1988 \\
5 \text { Oct }\end{array}$ & 1992 \\
\hline 6 & 国立がんセンター & 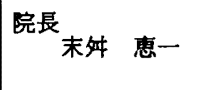 & $\begin{array}{l}\text { 胃がんの診断およ } \\
\text { び治㞠方法評価 }\end{array}$ & $\begin{array}{l}\text { T104 中央区策地 } 5-1-1 \\
\text { Tel : } 3542-2511, \\
\text { Fax : } 3545-3567\end{array}$ & 1970 & 1990 & 1994 \\
\hline 7 & $\begin{array}{l}\text { 国立公衆衙生院 } \\
\text { 地域環境釖生学 }\end{array}$ & 部長次夫 & 大気污染 & $\begin{array}{l}\text { T108 港区白金台 } 4-6 \text { - } 1 \\
\text { Tel }: 3441-7111, \\
\text { Fax : } 3446-4314\end{array}$ & 1970 & $\begin{array}{c}1989 \\
21 \mathrm{Dec}\end{array}$ & 1993 \\
\hline 8 & $\begin{array}{l}\text { 国立予防衙生研究所 } \\
\text { 体液性免没部 }\end{array}$ & 部長 & 兔疫学的生物製剤 & $\begin{array}{l}\text { T141 品川区上大崎 } 2-10-35 \\
\text { Tel : } 3444-2181, \\
\text { Fax : } 3446-6286\end{array}$ & 1971 & $\begin{array}{c}1988 \\
6 \mathrm{Apr}\end{array}$ & 1992 \\
\hline 9 & $\begin{array}{l}\text { 国立予防衛生研究所 } \\
\text { 学度部 }\end{array}$ & 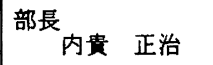 & 特定実釦動物 & $" 1$ & 1974 & $\begin{array}{l}1988 \\
31 \text { Aug }\end{array}$ & 1992 \\
\hline 䅂 & 国立環境研究所 & 所長 不破 敬一郎 & $\begin{array}{l}\text { 環境の保健に対す } \\
\text { る䧐都 }\end{array}$ & & 1976 & $\begin{array}{c}1983 \\
27 \text { Jul }\end{array}$ & 1987 \\
\hline 10 & 国立竞生試検所 & 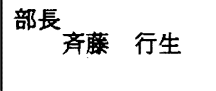 & $\begin{array}{l}\text { 食品中の有害物の } \\
\text { 視 }\end{array}$ & $\begin{array}{l}\text { T158 世田谷区上用賀 } 1-18-1 \\
\text { Tel : } 3700-1141 \text {, } \\
\text { Fax }: 3707-6950\end{array}$ & 1977 & $\begin{array}{c}1990 \\
3 \mathrm{Apr}\end{array}$ & 1994 \\
\hline 11 & 労㑺省産業医学総合 & 所長 & 職業衛生 & $\begin{array}{c}\text { 干213 川崎市多摩区長尾 6-21- } 1 \\
\text { Tel : 044-865-6111, } \\
\text { Fax : 865-6116 }\end{array}$ & 1977 & $\begin{array}{c}1988 \\
11 \text { Oct }\end{array}$ & 1992 \\
\hline 12 & $\begin{array}{l}\text { 国立がんセンター } \\
\text { 疫学部 }\end{array}$ & ${ }^{\text {部長 }}$ 渡遗 & 喫煙と健康 & $\begin{array}{l}\text { T104 中央区筮地 } 5-1-1 \\
\text { Tel : } 3542-2511, \\
\text { Fax : } 3546-0630\end{array}$ & $\begin{array}{l}1978 \\
\text { Sept }\end{array}$ & $\begin{array}{c}1988 \\
8 \mathrm{Apr}\end{array}$ & 1992 \\
\hline 13 & $\begin{array}{l}\text { (財)放射線影耪 } \\
\text { 研究所 }\end{array}$ & $\begin{array}{c}\text { 常務理事川 豊 } \\
\text { 長谷 }\end{array}$ & 人体に対する放射 & $\begin{array}{l}\text { T730 広島市南区比治山公園 5-2 } \\
\text { Tel : 082-261-3131, } \\
\text { Fax : 263-7279 }\end{array}$ & $\begin{array}{l}1979 \\
\text { May }\end{array}$ & $\begin{array}{c}1989 \\
18 \mathrm{Apr}\end{array}$ & 1993 \\
\hline 14 & \begin{tabular}{|l} 
順天堂大学医学部 \\
眼科
\end{tabular} & 教授 & 失明予防 & $\begin{array}{l}\text { T113 文京区本郷 } 2-1-1 \\
\text { Tel }: 3813-3111, \\
\text { Fax }: 3817-0260\end{array}$ & $\begin{array}{l}1980 \\
\text { Jan }\end{array}$ & $\begin{array}{l}1991 \\
\text { Jun }\end{array}$ & 1995 \\
\hline 15 & $\begin{array}{l}\text { 長崎大学医学部 } \\
\text { 精神神経科 }\end{array}$ &  & $\begin{array}{l}\text { 精神保健に関する } \\
\text { 研究・訓練 }\end{array}$ & $\begin{array}{l}\text { T852 長崎市坂本町12- } 4 \\
\text { Tel : 0958-47-2111, } \\
\text { Fax : 49-4372 }\end{array}$ & $\begin{array}{c}1980 \\
\text { Jul }\end{array}$ & $\begin{array}{c}1989 \\
31 \mathrm{Jan}\end{array}$ & 1993 \\
\hline 16 & $\begin{array}{l}\text { 聖マリアンナ医科大学 } \\
\text { 免学病害動物学 }\end{array}$ & $\begin{array}{l}\text { 名誉教授 } \\
\text { 神錬造 }\end{array}$ & $\begin{array}{l}\text { 妏およびその他の } \\
\text { 疾病媒介動物の遺 } \\
\text { 臸 }\end{array}$ & $\begin{array}{l}\text { T } 189 \text { 川崎市宮前区菅生 2-16-1 } \\
\text { Tel : 044-977-8111, } \\
\text { Fax : } 975-3315\end{array}$ & $\begin{array}{l}1981 \\
\text { Sept }\end{array}$ & 1988 & 1992 \\
\hline 17 & \begin{tabular}{|l} 
国立長崎中央病院 \\
塸床研究部
\end{tabular} & 部長 $_{\text {矢野 右人 }}$ & ウイルス性肝炎 & $\begin{array}{l}\text { 干856 大村市久原 2-1001-1 } \\
\text { Tel : 0957-52-3121, } \\
\text { Fax : } 53-6675\end{array}$ & $\begin{array}{c}1981 \\
21 \text { Oct }\end{array}$ & - & 1984 \\
\hline 18 & $\begin{array}{l}\text { 東京大学医学部 } \\
\text { 放射線医学 }\end{array}$ & 教授佐々木 康人 & 画像診断 & $\begin{array}{l}\text { T113 文京区本郷 } 7-3-1 \\
\text { Tel }: 3815-5411, \\
\text { Fax : } 5689-8218\end{array}$ & $\begin{array}{c}1982 \\
11 \mathrm{Mar}\end{array}$ & $\begin{array}{c}1987 \\
26 \mathrm{Oct}\end{array}$ & 1991 \\
\hline 19 & $\begin{array}{l}\text { 筑波大学医学専門 } \\
\text { 学群基礎医学 }\end{array}$ & $\begin{array}{c}\text { 名誉教授 } \\
\text { 㼈岡 一男 }\end{array}$ & $\begin{array}{l}\text { 日本住血吸虫の水 } \\
\text { 陸両生宿主の科 } \\
\text { 学的殺貝おざう } \\
\text { ボラトリー培䖯 }\end{array}$ & $\begin{array}{l}\text { 厂305 つくば市天王台 } 1 \text { - } 1 \text { - } 1 \\
\text { Tel : 0298-53-3210, } \\
\text { Fax : } 53-3039\end{array}$ & $\begin{array}{l}1982 \\
1 \text { Oct }\end{array}$ & 1991 & 1995 \\
\hline 20 & $\begin{array}{l}\text { (財)結核予防会 } \\
\text { 結核研究所 }\end{array}$ & 所長 青木 正和 & 結核の訓練・研究 & $\begin{array}{c}\text { T204 渏瀬市松山 } 3-1-24 \\
\text { Tel }: 0424-93-5711, \\
\text { Fax : 92-4600 }\end{array}$ & $\begin{array}{c}1983 \\
12 \text { Aug }\end{array}$ & $\begin{array}{c}1988 \\
16 \mathrm{Mar}\end{array}$ & 1991 \\
\hline
\end{tabular}




\begin{tabular}{|c|c|c|c|c|c|c|c|c|}
\hline 21 & $\begin{array}{l}\text { 島根医科大学 } \\
\text { 第二病理学 }\end{array}$ & 教授 $_{\text {家森 }}$ & 幸男 & $\mid$ & \begin{tabular}{|l} 
₹693 出零市塩治町89- 1 \\
Tel $: 0853-23-2111$, \\
Fax : $22-9277$
\end{tabular} & $\begin{array}{c}1983 \\
16 \mathrm{Sep}\end{array}$ & $\begin{array}{c}1991 \\
10 \text { Aug }\end{array}$ & 1995 \\
\hline 22 & $\begin{array}{l}\text { 日本医科大学付属 } \\
\text { 中央龟子頭锺鏡施 }\end{array}$ & $\begin{array}{c}\text { 施設長, 教 } \\
\text { 相原 }\end{array}$ & & 奄子頭徽鏡 & $\begin{array}{l}\text { 干113 文京区千駄木 } 1 \text { - } 1 \text { - } 5 \\
\text { Tel : } 3822-2131, \\
\text { Fax : } 5685-5517\end{array}$ & $\begin{array}{c}1984 \\
7 \text { Mar }\end{array}$ & $\begin{array}{c}1988 \\
28 \mathrm{Oct}\end{array}$ & 1992 \\
\hline 23 & $\begin{array}{l}\text { 東大医学部付呞病院 } \\
\text { 中央棈報部 }\end{array}$ & 教授 & 成充 & 医療情報 & $\begin{array}{l}\text { T113 文京区本郷 } 7-3-1 \\
\text { Tel : 3815-5411, } \\
\text { Fax : } 3813-7238\end{array}$ & $\begin{array}{l}1984 \\
2 \text { Jul }\end{array}$ & $\begin{array}{l}1988 \\
26 \mathrm{Jul}\end{array}$ & 1992 \\
\hline 24 & $\begin{array}{l}\text { 日本放射線技師会 } \\
\text { 教育センター }\end{array}$ & ${ }_{\text {中会長 }}$ & 実 & 医療放射線技師訓 & $\begin{array}{l}\text { T510-02 鉿鹿市岸岡町1001 } \\
\text { Tel : 0593-82-8271, } \\
\text { Fax : 83-2960 }\end{array}$ & $\begin{array}{l}1985 \\
8 \text { Jan }\end{array}$ & $\begin{array}{l}1989 \\
7 \text { Sep }\end{array}$ & 1993 \\
\hline 25 & \begin{tabular}{|l} 
東京女子医科大学 \\
形成外科
\end{tabular} & 教授 $_{\text {野椅 }}$ & 幹弘 & 熱㑺予防治療 & $\begin{array}{l}\text { T162 新宿区市ヶ谷河田町 } 10 \\
\text { Tel }: 3353-8111, \\
\text { Fax }: 5269-4780\end{array}$ & $\begin{array}{c}1985 \\
17 \mathrm{Apr}\end{array}$ & $\begin{array}{l}1990 \\
\text { Mar }\end{array}$ & 1994 \\
\hline 26 & $\begin{array}{l}\text { 国立仙台病院臨床研 } \\
\text { 究部 ウイルスセン } \\
\text { ター }\end{array}$ & $\begin{array}{c}\text { 臨床研究部 } \\
\text { 沼崎 }\end{array}$ & 祁長 & $\begin{array}{l}\text { ウイルス性呼吸器 } \\
\text { 疾患 }\end{array}$ & $\begin{array}{l}\text { 干984 仙台市宮城野区宮城野 2-8-8 } \\
\text { Tel : 0222-293-1111, } \\
\text { Fax : 291-8114 }\end{array}$ & $\begin{array}{c}1985 \\
30 \mathrm{Apr}\end{array}$ & $\begin{array}{c}1989 \\
18 \text { May }\end{array}$ & 1993 \\
\hline 27 & 国立病院医療センター & 院長 & 史磨 & 国際保健医療 & $\begin{array}{l}\text { T162 新宿区戸山 } 1 \text {-21- } 1 \\
\text { Tel : 3202-7181, } \\
\text { Fax : } 3207-1038\end{array}$ & $\begin{array}{c}1985 \\
13 \text { May }\end{array}$ & $\begin{array}{c}1989 \\
23 \text { May }\end{array}$ & 1993 \\
\hline 28 & 都立老人総合研究所 & 所長 & 享 & 老人保健 & $\begin{array}{c}\text { T173 板橋区栄町 } 35-2 \\
\text { Tel }: 3964-3241, \\
\text { Fax }: 3579-4776\end{array}$ & $\begin{array}{l}1986 \\
18 \text { Jun }\end{array}$ & $\begin{array}{l}1991 \\
\text { Oct }\end{array}$ & 1995 \\
\hline 29 & $\begin{array}{l}\text { 北里研究所 付属 } \\
\text { 東洋医学研究所 }\end{array}$ & $\begin{array}{l}\text { 名誉所長 } \\
\text { 矮 }\end{array}$ & 道明 & 伝統医学 & $\begin{array}{c}\text { T108 港区白金 } 5-9-1 \\
\text { Tel }: 3444-6161, \\
\text { Fax }: 3440-3992\end{array}$ & $\begin{array}{c}1986 \\
12 \mathrm{Feb}\end{array}$ & $\begin{array}{l}1990 \\
2 \mathrm{Mar}\end{array}$ & 1994 \\
\hline 30 & 国立循懪器病センター & ${ }^{\text {総長 }}$ 尾前 & 照雄 & 循環器病 & $\begin{array}{l}\text { 个565 吹田市藤白台 } 5-7-1 \\
\text { Tel : 06-833-5012, } \\
\text { Fax : 872-7483 }\end{array}$ & $\begin{array}{c}1986 \\
19 \mathrm{Feb}\end{array}$ & 1990 & 1994 \\
\hline 31 & 国立水俣病研究セン & 所長 ${ }_{\text {加藤 }}$ & 寬夫 & 有機水銀の健康影 & $\begin{array}{l}\text { 于867 水俣市浜4058-18 } \\
\text { Tel : } 0966-63-3111, \\
\text { Fax : } 63-6844\end{array}$ & $\begin{array}{c}1986 \\
24 \text { Sep }\end{array}$ & - & 1990 \\
\hline 32 & $\begin{array}{l}\text { 国妾医療 - 病院管理 } \\
\text { 研究所 }\end{array}$ & 所長 & 定請 & $\begin{array}{l}\text { 医療施設の計画と } \\
\text { 酸 }\end{array}$ & $\begin{array}{l}\text { 干162 新宿区戸山 1-21-13 } \\
\text { Tel : } 3203-5327, \\
\text { Fax : } 3202-6853\end{array}$ & $\begin{array}{l}1986 \\
8 \text { Oct }\end{array}$ & 1990 & 1994 \\
\hline 33 & $\begin{array}{l}\text { 国立公衆衛生院 } \\
\text { 廃莱物工学室 }\end{array}$ & 室長 & 勝 & 察亲物処理 & $\begin{array}{l}\text { T108 港区白金台 } 4-6-1 \\
\text { Tel }: 3441-7111, \\
\text { Fax : } 3446-4830\end{array}$ & $\begin{array}{l}1986 \\
3 \mathrm{Dec}\end{array}$ & $\begin{array}{l}1991 \\
\text { May }\end{array}$ & 1995 \\
\hline 34 & $\begin{array}{l}\text { 国立公衆衛生院 } \\
\text { 衛生工学部 }\end{array}$ & 部長 & 泰基 & 地域への水の供給 & $\begin{array}{l}\text { T108 港区白金台 } 4-6 \text { - } 1 \\
\text { Tel }: 3441-7111, \\
\text { Fax : } 3446-7161\end{array}$ & $\begin{array}{l}1986 \\
3 \mathrm{Dec}\end{array}$ & $\begin{array}{l}1991 \\
\text { May }\end{array}$ & 1995 \\
\hline 35 & 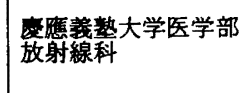 & 辖師 & 満 & $\begin{array}{l}\text { 呼吸器疾患の内視 } \\
\text { 鏡㻅断 }\end{array}$ & $\begin{array}{c}\text { T160 新宿区信灣町 } 35 \\
\text { Tel }: 3353-111, \\
\text { Fax }: 3225-5715\end{array}$ & $\begin{array}{c}1987 \\
12 \mathrm{Mar}\end{array}$ & - & 1991 \\
\hline 36 & $\begin{array}{l}\text { 京都大学ウイルス研 } \\
\text { 究所 }\end{array}$ & 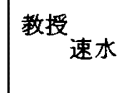 & 正憲 & AIDS & $\begin{array}{l}\text { ₹606 京都市左京区聖護院河原町53 } \\
\text { Tel : 075-751-4035, } \\
\text { Fax : 761-5626 }\end{array}$ & $\begin{array}{l}1987 \\
10 \mathrm{Jul}\end{array}$ & - & 1991 \\
\hline 37 & $\begin{array}{l}\text { 北黒研究所 } \\
\text { 訮䠰病研究センター }\end{array}$ & センター多一 & 長 & ウイルス性肝炎 & $\begin{array}{l}\text { T108 港区白金 } 5-9-1 \\
\text { Tel }: 3444-6161, \\
\text { Fax : } 3444-6637\end{array}$ & $\begin{array}{c}1987 \\
16 \text { Oct }\end{array}$ & - & 1991 \\
\hline 38 & $\begin{array}{l}\text { 産業医科大学 産業 } \\
\text { 態科学研究所 }\end{array}$ & ${ }^{\text {所長 }}$ 土屋 & 健三郎 & 産業医学 & $\begin{array}{l}\text { ₹807 北九州市八幡西区医生ヶ丘 } 1 \\
\text { - } 1 \\
\text { Tel : 093-603-1611, } \\
\text { Fax : } 691-1865\end{array}$ & $\begin{array}{c}1988 \\
14 \mathrm{Mar}\end{array}$ & - & 1992 \\
\hline 39 & $\begin{array}{l}\text { 富山医病科莞和科大吿喰 } \\
\text { 部 }\end{array}$ & 部長 & 揟年 & 云統医学 & $\begin{array}{l}\text { ₹930-01 富山市杉谷2630 } \\
\text { Tel : } 0764-34-2281, \\
\text { Fax : } 34-1463\end{array}$ & $\begin{array}{c}1988 \\
23 \mathrm{Apr}\end{array}$ & - & 1992 \\
\hline 40 & $\begin{array}{l}\text { 鹿児島大学医学部 } \\
\text { 第三科 }\end{array}$ & 教授 & 光弘 & $\begin{array}{l}\text { ヒト・レトロヴ } \\
\text { ルス性神経疾患 }\end{array}$ & $\begin{array}{l}\text { 于890 鹿児島市宇宿町1208- } 1 \\
\text { Tel }: 0992-64-2211, \\
\text { Fax }: 65-7164\end{array}$ & $\begin{array}{c}1988 \\
13 \text { Oct }\end{array}$ & - & 1992 \\
\hline 41 & $\begin{array}{l}\text { 国立京都病院 } \\
\text { 臨床研究部 }\end{array}$ & 部長 & 好温 & 糖尿病 & $\begin{array}{l}\text { T612 京都市伏見区樑草向畑町 } 1-1 \\
\text { Tel }: 075-641-9161, \\
\text { Fax : } 645-4339\end{array}$ & 9 Nov & - & 1992 \\
\hline 42 & $\begin{array}{l}\text { 国立療圽所 } \\
\text { 久荲浜病院 }\end{array}$ & 院長 & 裕明 & $\begin{array}{l}\text { アフルコール成連障 } \\
\text { 害 }\end{array}$ & $\begin{array}{c}\text { T239 横須賀市野比2769 } \\
\text { Tel : } 0468-48-1550 \\
\text { Fax : } 49-7743\end{array}$ & $\begin{array}{r}1989 \\
4 \mathrm{Jan}\end{array}$ & - & 1993 \\
\hline 43 & 埼玉県立がんセンター & 院長 & 文和 & 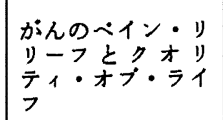 & $\begin{array}{l}\text { \%362 埼玉県北足立郡伊奈町大字小室 } \\
\text { 818 } \\
\text { Tel : 048-722-1111, } \\
\text { Fax : 722-1129 }\end{array}$ & $\begin{array}{l}1990 \\
1 \text { Jun }\end{array}$ & - & 1994 \\
\hline
\end{tabular}




\begin{tabular}{|c|c|c|c|c|c|c|c|c|}
\hline 44 & 聖路加看護大学 & $\begin{array}{l}\text { 学部長 } \\
\text { 常葉 }\end{array}$ & 恵子 & $\begin{array}{l}\text { ブライマリーへル } \\
\text { スケフー看讙開発 }\end{array}$ & $\begin{array}{l}\text { T104 中央区明石町10- } 1 \\
\text { Tel : } 3543-6391, \\
\text { Fax }: 5565-1626\end{array}$ & $\begin{array}{c}1990 \\
20 \mathrm{Apr}\end{array}$ & - & 1994 \\
\hline 45 & $\begin{array}{l}\text { 東北大学医学部 } \\
\text { 公衆衛生学 }\end{array}$ & ${ }^{\text {教授 }}$ 久道 & 茂 & $\begin{array}{l}\text { 地域における高埋命 } \\
\text { 者福祉 }\end{array}$ & $\begin{array}{l}\text { 干980 仙台市青莱区星凌町 } 2-1 \\
\text { Tel : } 022-274-111 \text {, } \\
\text { Fax : } 275-4877\end{array}$ & $\begin{array}{c}1991 \\
27 \mathrm{Feb}\end{array}$ & - & 1995 \\
\hline 6 & $\begin{array}{l}\text { 大阪府立母子保健 } \\
\text { 総合医療センター }\end{array}$ & 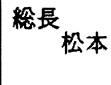 & ケイシ & 母子保健 & $\begin{array}{l}\text { T590-02 和泉市室堂町840 } \\
\text { Tel : 0725-56-1200, } \\
\text { Fax : 56-5682 }\end{array}$ & $\begin{array}{l}1991 \\
\text { July }\end{array}$ & - & 1995 \\
\hline & $\begin{array}{l}\text { 東京医科歯科大学 } \\
\text { 神経精神医学 }\end{array}$ & 教授 & 道男 & $\begin{array}{l}\text { 生物学的精神医学 } \\
\text { 及 }\end{array}$ & $\begin{array}{l}\text { T113 文京区淂禹 } 1-5-45 \\
\text { Tel : } 3813-6111, \\
\text { Fax : } 3818-7180\end{array}$ & $\begin{array}{c}1991 \\
11 \text { Sep }\end{array}$ & - & 1995 \\
\hline 8 & $\begin{array}{l}\text { 東京医科大学 } \\
\text { 公采御学 }\end{array}$ & 教授 $_{\text {岩根 }}$ & 久夫 & $\begin{array}{l}\text { 健康增進のため医学 } \\
\text { スホ }\end{array}$ & $\begin{array}{l}\text { T160 新宿区新宿 6-1-1 } \\
\text { Tel : } 5379-4339, \\
\text { Fax : } 3353-0162\end{array}$ & $\begin{array}{l}1991 \\
\text { Dec }\end{array}$ & - & 1995 \\
\hline
\end{tabular}

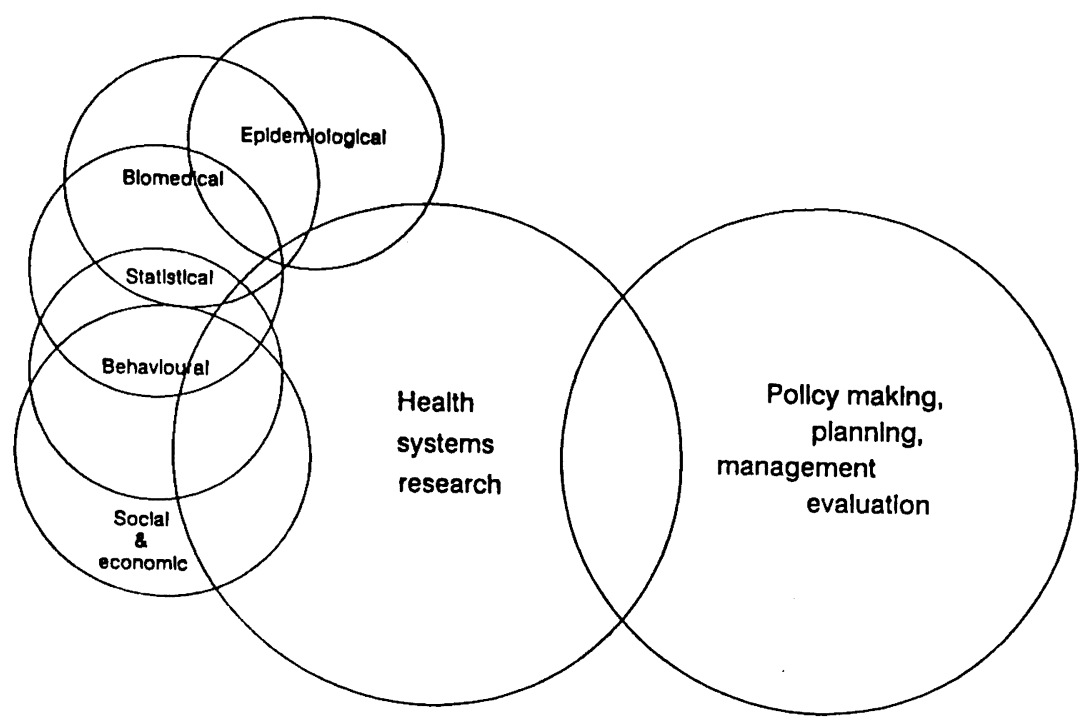

図 5 Model of the relationship between different types of research, health systems research and the management process ${ }^{31}$.

research council(その類似組織, 国家としての情 報 centre としての focal point (FP), regional training centre と共軘せしめ, 一定の研究協約 (terms of reference) のもとで活動させている21) (表 5 ). National research council を中心とした 各地域所属国家の健康研究政策を表 4 に示す. 尾 前らは22), 国立循環器センターとしての活動目標 を次のよらに定めている。すすなわち，(1)医学情報 の相互交換，(2)人材交流，人的資源の育成，(3)こ れらの実績をふまえた上での協同研究の立案, 実 施. これらの基準は単に循環器病といら限定され た分野だけでなく，すべての分野の基準として適 合しらるものと考えられる。医療技術の国際化を
考えるときに，次の諸要件を念頭におく必要があ ろら。すなわち，i）技術移転にともなら適切な技 術の特定 (delineation of appropriate technology)，すへてての技術を総花的に移転をこころみる のは相手方の環境とそれをらけいれる社会基盤 (infrastructure), 技術力, 経済的背景等の問題が あり適切でない. Regional training centre として の性格をむつマレーシア国立医学研究所で実行さ れているよらに特定指定研究 (Intensification of research in priority area (IRPA)) を特定し, それから技術移転を実行していくのも一つの有効 な方法であろらと考えられる。 


\section{9. 健康分里における技術移転の問題点}

現在，各分野での技術移転の重要性がさけばれ ているが，必らずしも十分効果を発揮していない ららみがある.その大きな要因は移転者(transferrer）から譲受者（transferee）への技術移転のと きに必然的にともなら知的所有権とか resource の所属についての見解がはっきりしていないこと にある.これらの点についてす早急に明確にする 必要がある。このような問題認識のもとで GCHR, WPRCHR 等の活動と共軘すれば, 将来 我国の医学面での国際貢献は期して挨つものがあ ると考えられる(図 5)，現在，とくに優先研究主 題と考えられているものにはヒトの生殖機構, 熱 帯病, AIDS/HIVをふくむ感染症, 下症症, 栄養 問題, 環境污染にともなら疾患, 事故, 大型災害, 医療技術移転等, 多くの諸問題があげられてい る23).このような諸問題の global level でのとり あつかいモデルとして, すでに environmental epidemiology networkが確立され た 21,24 27,28,29). 今後多くの問題についてこのよ5 なアプローチが実行に移されることが予測され $3^{30)}$.

当研究施設では電子顕徽鏡を中心とした研究研 修活動の場を提供してきた。今後この分野での global information network の整備, 電顕診断学 の診断基準, normenclature，技術の標準化，他の 先端技術の導入と，その応用についての教育研究 モシュールを作成するとともに，諸外国に打ける 研究施設との協同研究を推進し, 真の国際的研究 研修センターとしての基盤を確立したいと考えて いる.

\section{おわりに}

医学教育, 研究の改善がさけばれ 21 世紀への模 索がつつけられている今日，その明確な指針をも つことは容易ではない，それについて考えるまえ に本稿においてのべたような医学教育, 研究の上 で，将来影響を拉よぼすであろらと考えられる潮 流をさぐることは，決して無䭾ではないと考え浅 学菲才をかえりみず執筆を試みた。当研究施設の 活動の基本的理念の策定にあたっては，これらの
潮流をすへて基本において考えており，今後，学 の内外の御指導をえて国際医学交流の一試金石と して発展させることを期するものである.

稿を終えるにあたり多年にわたり御指導，御叱正いたた いている世界保健機関本部事務総長中鳰 宏博士，同西太 平洋事務局長 S.T. Han 博士，同前研究開発部長 Y.H. Paik 度熙大学教授, WRPO, WHO Sima Hailan 博士, 日本国厚生省大臣官房国際課の諸先生に深謝する，本講演 の機会をお与えいただき終始御指導いただいている日本医 科大学医学会長庄司祐学長に深謝する。充た，終始御支 援いたたいている日本医科大学理事長，大塚敏文教授に感 謝するとともに，医学教育について多大の御教示, 御叱正 をいただいている日本医学教育学会、牛場大藏会長，国際 関係委員会尾島昭次委員長に深謝する。

なお，本稿の要旨は平成 2 年 9 月日本医科大学医学会総 会においてのべたものにもとついており，すへてて執筆者の 個人的見解であり，いかなる公的機関のそれをも代表する ものではないことを附記する。

\section{文 献}

1）藤井正直：実りある留学生制度の推進を望む．医学教 育, 22, 1, 1991.

2）相原 兴: アジフ太平洋地域医学教育会議出席報告. 医学教育, 14，437 442，1986.

3）相原 葶：国際医学交流の現状と将来. 世界保健機関 (WHO) 研究研悲力センターの活動よりみて。新医 療, $29 \sim 34,1986$.

4) 相原 兴, 田中満, 渡辺度一: 国際化と医学教育, 医学研究の将来：すべての人々に健康を。新医療，5, 104 109, 1987.

5) Proceed, National Training Course in Use of Electron Microscope for Biomedical Researches, WHO. MOPH. PRC. \& Xian Medical University, 1986.

6) Proceed, National Training Course of Electron Microscopy in Biomedical Research and Diagnosis of Human Diseases, WHO, MOPH. PRC. \& Capital Institute of Medicine, Beijing PRC. 1990.

7) Proceed, Bi-Regional Training Course on Electron Microscopy in Bio-Medical Research and Diagnosis of Human Diseases SEARO, WRO, WHO, Chularonkorn University, Bankok, 1991.

8) Annual Report, 1991 School of Medical Education Uni. of New South Wales \& WHO Regional Training Centre for Health Development, 1991.

9）路振富：中日医学教育の比較、日本医事新報, 3270 , $46 \sim 49,1986$.

10) Neufeld, V.R.: Adventures of an adlescent ; Cur- 
riculum changes at MacMaster. University in the New Biology and Medical Education. Triedman, C. P., Purcell, F.F., Eds. Macey, J., Foundation, Jr. N. Y. 1990.

11）丸井英二：医学部留学生と医学教育の国際化. 医学教 育, 22, 20 24, 1991.

12）石森 章：医療の国際化；一国健康主義からの脱却。 総合医学社, 東京, 1991.

13）西園富久：医学教育はどら改善されるべきか。医学振 興, 11, 20, 1986.

14）日本学術会議：日本における解剖学の教育と研究（現 状の考察と将来への展望). 解剖学研究連絡委員会報 告, $9,21,1990$.

15) Report of Meeting of Directors of Health Research Councils or Analogous Bodies. WPRO. WHO, 1989.

16) Report 13th. Session, Western Pacific. Advisory Committee on Health Research, WPRO. WHO, 1990.

17) Hodge, J.U.: International Cooperation in Health Research and Technology Transfer Through National Health Research Councils (NHRCS), or Analogous Bodies. WPACHR, Report, 1986.

18）松村豪一：第 1 回長崎大学医学教育ワークショップ報 告書, 1991.

19) A step-by-step guide to writing an annual report for WHO collaborating centres. WPRO. WHO, 1988.

20) Ventura, E.: Evaluation of research grants, research. training/visiting scientits grants and research design and methodology course, report, WPRO. WHO, 1990.

21) Inventory of basic textbooks in epidermology. Environmental and Occupational. Health, WHO.
Geneva, 1998.

22）尾前照雄：International symposium on cardiovascular researches. 国際循環器センター, 大阪, 1986.

23) WHO. Research activities biennial, 1985 1986, $\mathrm{RPD} / \mathrm{COM} / 92,1986$.

24) Kjellström, T.; Formulation of WHO envirnomental Epidemiology Network, WHO, Information Sheet, 1986.

25) Inventory of audiovisual materials : Environmental \& occupational epidermiology WHO. Geneva, 1990.

26) Inventory of ongoing research in occupational health 8 enuironmental epidemiology in developing countries, WHO. Geneva, 1990 1991.

27) Greent list of participant. Environmental \& occupational epidermiology series, WHO, 1991.

28) Promblem-based training Exercises for environmental epidermiology instructurs's . Guide ; Enviromental \& occupational epidemiology series, Geneva, WHO. 1991.

29) Investiguting enuironmental disease out environmental \& occupational breal epidemiology. Breasks : A training manual. Dec., 1991.

30) Reference information for environmental health training and research. WHO. Geneva, 1992.

31) Paik, Y.H., Ko U.R. and Pathway K.M.: Health research methodology a guide for training in research medithods WHO Regional Publications. western Pacific Education in Action Series, No. 5, 1992.

（受付：1992 年 7 月 17 日） 